\title{
THE COMPARISONS AND CONTRASTS BETWEEN ENGLISH AND MALAY LANGUAGES
}

\author{
Mohd Nazri Latiff Azmi \\ Lidwina Teo Pik Ching \\ Norbahyah Binti Jamaludin \\ Muhammad Nur Haziq Bin Ramli \\ Muhammad Habibbullah Bin Razali \\ Muhammad Ammar Yasser Bin Amram \\ Kauselya A/P Jayakumar \\ Universiti Sultan Zainal Abidin, Malaysia \\ Email: $\underline{\text { mohdnazri@unisza.edu.my }}$
}

APA Citation: Azmi, M. N. L., Ching, L. T. P., Norbahyah, Haziq, M. N., Habibullah, M., Yasser, M. A., \& Jayakumar, K. (2016). The comparison and contrasts between English and Malay languages. English Review, 4(2), 209-218

Received: 22-02-2016

Accepted: 29-03-2016

Published: 01-06-2016

\begin{abstract}
English and Malay languages are categorized as popular languages in the world. However, both languages underwent different history and composition. This study investigates the languages in terms of history, phonology, loanwords, grammar, morphology and semantics. The purposes of studying the comparisons and contrasts of both languages are not only to analyze the uniqueness of the languages but also to identify the process of understanding the languages especially the view of second language learners. It is found that two languages come from different background; somehow they share similar characteristics such as the vowels sounds, loanwords and semantics. However, the learners face difficulty in learning both languages especially in pronunciations and spelling. Keywords: English language, Malay language, history of language
\end{abstract}

\section{INTRODUCTION}

Language is a complex way of communication that is used by human beings to communicate with each other; there are tons of different languages that are used by people today and more yet to be discovered. There are scientific studies of languages called as linguistics as scientists learn about the comparison and contrast of pronunciation and grammatical structure of a language. As languages gradually develop and expand, they started to have their structure that every language has its unique structures and different from one another. Beginning with the sound system to meaning also known as semantics, they form the foundation of a language. Acquiring a language implies acquiring all those structures. This paper aims to compare and contrast two different languages that are English and Malay.

Both of the languages can be divided into three periods. For English language, history can be explained through three phases which are Old English (450-1100 AD), Middle English (1100-1500 AD) and Modern English (1500 AD). On the other hand, for Malay Language, Old Malay (682-1500 C.E), Modern Malay (c.1500-1957) and Contemporary Malay (1957) were three significant periods in whole Malay history. 
The beginnings of these languages slightly differ from one another. For Old English, three Germanic tribes (Saxon, Angles, \& Jutes) came to the British Isles from various parts of northwest Germany at $5^{\text {th }}$ century AD. These tribes were warlike and pushed out most of the original, Celtic-speaking inhabitants from England to Scotland, Wales and Cornwall. One group migrated to Brittany Cost of France where their descendant still speaks the Celtic Language of Breton today. Through the years, the Saxon, Angles, Jutes mixed their difference Germanic dialects. This group of dialects forms what linguists refer as Old English whereas old Malay begins with records of poems and thoughts on writing material made from plants described as the sharp cursive Rencong, an ancient script believed to be native to South-East Asia (Nor Hashimah, 2004).

Both of the languages do have influences from other languages in some aspects. In the history of English language, the Latin language played a role. Roman came to Britain and brought Latin to Britain which was part of the Roman Empire for over 400 years. Many word passes on from this era and those corned by Roman Merchants and soldier. Examples of word used such as Win (Wine), Candel (Candle), Belt (belt) and Weal (wall). The arrival of St. Augustine in 597AD and the introduction of Christianity into Saxon England brought many words into English Language. There were mostly concerned with naming of church, dignitaries, and ceremonies. Church, Bishop, baptism came indirectly from Latin. Other than that, Celtic language brought changes. This Celtic language was seen in names of rivers. For instance, Kent, York, Dover, Cumberland, Thames, Avon, Trent etc. In addition, Norse language or
Scandinavian language brought influence in English Language. Around 878 AD, Danes and Norsemen called Vikings invaded the country and English got many Norse words including sky, egg, cake, skin, window, husband, call, die, etc. Furthermore, in Middle English, the French language contributes its influence. By about 1200, England and France had split, English changed a lot because it was mostly being spoken instead of being written for about 300 years. The period of Old English was almost over after William the Conqueror, The Duke of Normandy and his nobles who spoke French and Middle English was being formed. Examples of Old English word used such as Crown, Castle, Parliament, Banquet, art, poet, romance, servant (Newmark, 1988).

According to Nik (1989), in the history of Malay language, a few languages influence in it. At the beginning of old Malay, many Pallava words from Vatteluttu, India bring changes in Malay language. This is due to Indians set feet on Malay Archipelago. Other than that, Sanskrit brings influenced in Malay vocabulary. Examples of words used such as Agama, Akasara, Angkasa, Anugerah, Bahasa, Bakti, Bangsa, Barat, Biara, Bidadari. Portuguese language also brought changes in the Malay language. In the year 1511, the Portuguese conquered Malacca and Latin Alphabets in place of Jawi writing called Rumi. Although the conquest is short lived, the impact of Portuguese Language is large. Words used in Portuguese Language are Almari, Baldi, Bangku, Biola.

\section{METHOD}

This comparative study involves only document analysis in which established and well-accepted texts pertaining to the contexts, processes and 
procedures were scrutinized and analyzed. A thorough study of the important elements of both languages we checked and corrected by several experienced linguists of both languages and given a serious concern.

\section{RESULTS AND DISCUSSION}

The phonology of English and Malay languages is different in the quantity of vocals and diphthongs, place and manner of articulation. In English sound system, there are 12 vocals, 24 consonants and 8 diphthongs whereas there are 6 vocals, 27 consonants (19 native consonants and 8 consonants that appear only in borrowed words) and 3 diphthongs in Malay sound system. (Tien-Ping Tan, Bali Ranaivo-Malançon).

The vocals that are similar in English and Malay languages include [a], [e], [i], [o], [u] and schwa. For example, [a] sound appears in 'up' and 'awal' (early) respectively; [e] sound shows in 'bed' and 'enak' (tasty) accordingly; [i] sound appears in 'igloo' and 'ikan' (fish) respectively; [o] sound presents in 'opposite' as well as 'oleh' (by) accordingly; [u] sound appears in 'unicorn' and 'ubat' (medicine) respectively; schwa sound appears in 'awhile' and 'emak' (mother) accordingly. On the other hand, /æ/ in 'cat', / p / in 'hot', /i:/ in 'see' etc. are the instances for the vocals that are included in English phonology and different from Malay phonology.

Moreover, there are eight diphthongs in English phonology and three in Malay. In English phonology, they are /aI / in 'five', /av/ in 'now', /eI / in 'say', /ou/ in 'go', / כI / in 'boy', /еə/ in 'air', / Iə / in 'near' and / ๖ə/ in 'pure'. Meanwhile, in Malay phonology, they are /ai/ in 'kain' (cloth), /au/ in 'laut' (sea) and / oi/ in 'boikot' (boycott). These examples show that the three Malay diphthongs are the same as three of English diphthongs that are /aI /, /av/ and / JI / respectively.

There are seven important places of articulation in English according to Kristin Denham and Anne Lobeck, that are bilabial, labiodental, dental, alveolar, palatal, velar and glottal but Malay phonology has labio-velar and no labiodentals and dental sounds. For manner of articulation, both Malay and English phonologies have six manners with voiced and voiceless pronunciation respectively. In English, they are stop, fricative, affricate, nasal, approximant and glide. In Malay, they are plosive or affricate, fricative, nasal, trill, approximant and lateral. Two tables below show the consonant chart of both English and Malay Languages.

Based on the Table 1 and 2, it can be said that $[w]$ sound in 'one' is the example of glide in English but in 'wajar' (reasonable) is the example of approximant in Malay etc. It is undeniable that the sound $[\mathrm{b}]$ is similar in both English and Malay that are 'barber' and 'batik' (one type of cloth) as examples respectively (Murni, 2013). As we know, Malay language or Bahasa Melayu is the national language in Malaysia, while English is the second language and also the international language. Both of them are two important languages in Malaysia that began from British colonization. As we can see, Malay language tends to borrow a lot of English words rather than vice versa. English seems to be the dominant language in this case because some English loanwords in Malay are more than that of Malay loanwords in English. 
Mohd Nazri Latiff Azmi, et all.

The Comparisons and Contrasts Between English and Malay Languages

Table 1. International Phonetic Alphabet (IPA) Chart

\begin{tabular}{|c|c|c|c|c|c|c|c|c|c|c|c|c|c|c|c|}
\hline & \multicolumn{15}{|c|}{ Place of Articulation } \\
\hline \multirow{8}{*}{ 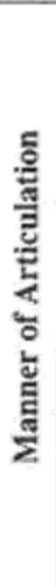 } & & \multicolumn{2}{|c|}{ Bilabial } & \multicolumn{2}{|c|}{$\begin{array}{l}\text { Labio } \\
\text { dental }\end{array}$} & \multicolumn{2}{|c|}{$\begin{array}{l}\text { Inter } \\
\text { dental }\end{array}$} & \multicolumn{2}{|c|}{ Alveolar } & \multicolumn{2}{|c|}{$\begin{array}{l}\text { Alveo- } \\
\text { palatal }\end{array}$} & Palatal & \multicolumn{2}{|c|}{ Velar } & \multirow[t]{2}{*}{ Glottal } \\
\hline & Stop & $\mathrm{p}$ & b & & & & & $\mathrm{t}$ & d & & 28 & & $\mathrm{k}$ & g & \\
\hline & Fricative & & & f & v & $\theta$ & o & $s$ & $z$ & $\int$ & 3. & & & 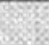 & $\mathrm{h}$ \\
\hline & Affricate & & 2 & & & & & & & t5 & d3. & & & E & \\
\hline & Nasal & & $\mathrm{m}$ & & & & & & $\mathrm{n}$ & & & $x$ & & n) & \\
\hline & $\begin{array}{l}\text { Lateral } \\
\text { Approximant }\end{array}$ & & & & & & & & 1. & & & & & & \\
\hline & $\begin{array}{l}\text { Retroflex } \\
\text { Approximant }\end{array}$ & & & & & & & & x. & & & & & & \\
\hline & Glide & $\mathrm{M}$ & w & & & & & & & & & 3 . & & & \\
\hline \multicolumn{16}{|c|}{ State of the Glottis } \\
\hline & oiceless & & & & & & & & iced & & & & & & \\
\hline
\end{tabular}

Table 2. Malay Consonant Chart

\begin{tabular}{|c|c|c|c|c|c|c|c|}
\hline & Labial & Alveolar & $\begin{array}{c}\text { Post- } \\
\text { alveolar* }\end{array}$ & Palatal & Velar & Glottal & $\begin{array}{c}\text { Labial- } \\
\text { velar }\end{array}$ \\
\hline Plosive/Affricate & $\begin{array}{ll}\mathrm{p} & \mathrm{b}\end{array}$ & t $\quad d$ & $\mathrm{t} \int \mathrm{d} z$ & & $\mathrm{k} \quad \mathrm{g}$ & (?) & \\
\hline Fricative & (f) (v) & s $\quad(\mathrm{z})$ & $\left(\int\right)$ & & (x) & $\mathrm{h}$ & \\
\hline Nasal & $\mathrm{m}$ & $\mathrm{n}$ & $\mathrm{n}$ & & y & & \\
\hline Trill & & $\mathrm{r}$ & & & & & \\
\hline Approximant & & & & $\mathrm{j}$ & & & W \\
\hline Lateral & & l & & & & & \\
\hline
\end{tabular}

According to Deterding (2013), a loanword is a word adopted from a foreign language with little or no modification. It also can be referred as a word borrowed from a donor language and incorporated into a recipient language without translation. It is distinguished from a 'calque' or loan translation whereby a meaning from another language is translated into existing words or roots of the host language. This type of translation remains the pronunciation of the word in the original language when the word is being translated into another language. English loanwords in Malay can be divided into a few categories. The first category is the loanword that remains its spelling for both languages and brings the same meaning. For example, 'atom' in Malay language is spelled the same as 'atom' in English. The other examples are drama, bonus and hotel.

Next, the English loanword has changes in its spelling but the pronunciation remains the same in Malay. For example, 'carbon' in English is translated into 'karbon' in Malay that is different in the first alphabet. Other instances are block (blok), script (skrip), graphic (grafik) and activity (activiti).

Besides that, there are few words in Malay that are being translated and became valid words in English recently. 
For example, the word 'lepak' which refers to hang out with friends, loiter about and do absolutely nothing. The other word is 'amok' which comes from Malay word 'amuk', refers to behave uncontrollably and disruptively. Other words in Malay that is being officially used in English are durian, nasi lemak, silat, gong and sarong.

In conclusion, it can be said that both of the languages have a correlation. We can see that they influence each other from the loanwords. There are numerous vocabularies in Malay that resemble in English. This shows that English had influenced the Malay language in vocabulary aspect.

According to Baker (2011), in grammar, there are similarities and contrasts between English and Malay languages such as field of tenses, plural and singular nouns. Among the field of tenses, there are past, present and future tenses. The past tense is a grammatical tense to show or indicate an event or situation in past time. Past tense in a sentence shows a grammatical tense to indicate the situation had occurred in the past. Usually, the verb to show past tense is to be added a suffix -ed. For example, the word 'walked'. The verb walk is added -ed to become 'walked'. However, not all the verbs can be added the suffix -ed such as the verb 'put'. For example, I put the book on my table last night.

In Malay Language, we do not have specific suffixes to indicate the situation happened in the past. For instance, if we want to say 'Ammar scored a goal', we would say 'Ammar telah menjaringkan gol'. The term 'telah' indicate that the event happened in the past. According to the website grammar.ccc.commnet.edu, the present tense refers to an action is present, now, about the speaker or writer. It is used to describe actions that are factual or habitual things that occur in the present but not necessarily happening right now. For example, 'My train leaves tomorrow morning'. The verb 'leaves' is a present tense although this situation shows an event that is going to happen. Usually in English, the usage of the suffix '-ing' is widely applied in present tenses. For instance, 'I am walking' for singular noun and 'We are walking' for plural noun (Imran, 2000).

In Malay Language, the original verb is not disturbed as we do not change the verb instead we use another term to show the situation happen in the past, present or future. For example, the sentence 'Saya sedang berjalan' is for singular subject and another sentence 'Kami sedang berjalan' is for plural subject. The word 'sedang' shows the action is going on at that time and the meanings of the Malay examples corresponded to that of English examples.

Future tense indicates an action that is going to happen in the future. This situation applies to a situation that is going to happen later, next day, next week or even next month.

According to englishpage.com, future tense has two different forms that are 'will' and 'going to'. For example, 'I will help him later' and 'You are going to meet Jane tonight'.

In Malay language, the term 'akan' is often used to indicate a future situation. For example, 'Saya akan membantu dia nanti' that means 'I will help him later'.

Besides, the forms of singular and plural nouns in English are also different from that in Malay. In English, most singular nouns form the plural by adding ' $-s$ ' and the examples are boats, cats and houses. However, it differs from Malay language as we do not add ' $-s$ ' to show that it is plural. We only use term 
'banyak' to show the plural meaning of the nouns. For instance, phrase 'seekor kucing' refers to one cat whereas 'banyak kucing' refers to many cats. On the other hand, there is also a singular noun ending in $s, x, z$, ch, sh need to be added '-es' and to make it plural in English such as buses, wishes and boxes.

Moreover, there is also a singular noun ending in a consonant $y$ and then it makes the plural by dropping the ' $y$ ' and adding '-ies' to make it plural. The instances penny (pennies), spy (spies) and baby (babies).

Morphology is an area in linguistics studies that investigates the structures, forms and categorizations of words of a language. Discussions on both Malay and English morphology will specifically touch on affixes, preposition, adverbs and superlatives. However, for today we are going to discuss in-depth more about affixes.

Like other dominant languages, Malay has pre-fixes, suffixes and infixes while in English, prefixes and suffixes are more prominent. The difference between Malay and English affixes is that English affixes can indicate or produce an element that has been added either to the beginning or the ending of a word.

For example, the root word 'car' is considered as the one and only car, we can change the meaning of the word by adding ' $s$ ' at the back of the word, becoming 'cars' that refers to more than one car. This is known as suffixation and it is quite challenging as compared to the others because it can change a word into a different part of tense or speech. However, unlike English affixes, Malay language tend to have different meaning depending on the usage of the affixes itself. Both suffix and prefix can change the meaning of a root word. For example, for the root word 'mati' which means death in English tends to have different meaning depending on its affixes. By adding suffix '-kan' to the word causing it to transform into the word 'matikan' that means switch off in English. For example, a sentence using the word 'matikan' in Malay might sound like this 'Aidan, tolong matikan generator $i t u$ ' that is translated into English and might sound like this 'Aidan, could u please turn off that generator'. This has completely brought different meaning and cannot be used to describe the death of something but used purposely to describe shut down or switch off things such as switches or engines. When you break a word apart and remove the prefixes and suffixes, you are left with the root. It's easier to determine the meaning of an unknown word if you know the root. For example, we might come across the word 'happy' that means feeling or giving pleasure (Hatim, 1997). However, most of us find it easier to recognize the word 'happy' than the prefix itself which is ' $u n-$ '. By adding the prefixes, the word will be totally opposite from the root word that is not feeling pleasure. This shows that affix plays an important role in English language. There are many prefixes in English, yet only 20 accounts for $97 \%$ of the words that contain prefixes. Learning these 20 prefixes and their meanings can make a big difference in your ability to recognize words and their meanings that can also help you to write a better essay with excellent grammatical structure.

Meanwhile, Bahasa melayu also has prefixes but the usage of the prefixed is different from that in English. For example, when you look into Malay dictionary especially Kamus Dewan Bahasa Dan Pustaka, you might find words like 'memandu' that refers to driving and might be thinking that it is a root word. The root word is 'pandu' that 
ENGLISH REVIEW: Journal of English Education Vol. 4, Issue 2, June 2016
ISSN 2301-7554

https://journal.uniku.ac.id/index.php/ERJEE means drive and ' $m e^{-}$' is the prefix of the word. This shows that the prefix in Malay is not similar as that in English because mostly the meanings of the root word and the word with prefix in English are opposite.

Not only that, prefixes in Malay can be used on most of the word and are productive, unlike the prefixes in English. For example, the prefix 'pe-' in Malay can be put on almost all words as it later will ring the same meaning such as 'pemakai' which means a user in English. Which somehow make it easier to be remembered and used compared to English affixes that are different. You may use the prefix 'un-' for 'unhappy' but not for the word 'engage' which will use prefix 'dis-' making it as 'disengage' instead. Even though they belong to the same negative prefix, they have different pronunciation, spelling and frequency compared to the Malay affixes that are the same on those three aspects depending on the words.

However, do take note that the tables above show the most common used affixes in Malay language especially during writing and oral communication. There are still tons of other affixes that are used in Malay as it is updated from time to time by the linguistics scholar back in the Dewan Bahasa dan Pustaka. Both of the languages affixes have the same goal that it to complete the sentence by putting different prefix or suffix for its meaning to suit the sentence itself. However, there is a slightly noticeable difference between both languages affixes which is the spelling, pronunciation and frequency.

Semantic is the field of study that examines the meaning of language. It is defined as the study of the meaning of words, phrases, and sentences in a language. According to Ferdinand de
Saussure, every linguistic sign consists of two elements, which are the signified and signifier. Ogden and Richards show the relationship between words, concepts, and objects referenced through a semantic triangle.

There are few similarities between Malay language and English language from the aspect of semantic. The similarities can be seen from the meanings of denotative and connotative and also from the lexical relations.

Denotation means an object or concept referred by a term or a set of objects of which a predicate is true while connotation is the abstract meaning or intension of a term, which forms a principle determining that objects or concepts it applies to such as the word heart. The denotation of the word refers it as the real heart that is triangular in shape, pumps oxygenated blood to all body parts to help us stay alive while the connotation is a symbol of love and affection. The connotation meaning makes us have a mindset like we always see the shape of a heart with red in color as the symbol of love. The denotative and connotative meaning in Malay language and English are the same respectively.

Lexical relations show how meaning of a word relates to each other. Lexical items contain information about category, form and meaning. The semantics relate to these categories then relate to each lexical item in the lexicon. Some relations between lexical items include synonym, antonym, and hyponym (Butt, 2000).

Synonym is a word or phrase that means exactly or nearly the same as another word or phrase in the same language. In Malay language, the word 'bijak' and 'cerdik' have the same meaning. Thus, it is a synonym. In English language, the words that share 
the similar meanings are 'wise' and 'clever'. The meanings are still the same even in other language. Therefore, the synonym of Malay language and English language are the same.

Antonym is a word opposite in meaning to another. A word may have more than one antonym. There are three categories of antonyms identified by the nature of the relationship between the opposed meaning which are gradable antonym, complementary antonym and relational antonym.

Gradable antonyms are typically pairs of adjectives that can be qualified by adverbs such as very, quite, extremely etc. In Malay language, this antonym is called 'antonimi taksiran'. For example, we can say 'the tickets were expensive' or 'the tickets were cheap'.

Since expensive and cheap are gradable antonyms, so we can qualify how expensive or cheap they were. This can be proven in a few sentences such as 'the tickets were more expensive than the previous one' and 'the tickets were very cheap' in English as well as 'tiket ini lebih mahal daripada yang dahulu' and 'tiket ini sangat murah' in Malay.

Complementary antonyms are pairs of words that are opposite in meaning and cannot be graded. They are mutually exclusive, that is, only one of them can exist at one time. This antonym is called 'antonimi penggenap' in Malay language. For example, there might be a newborn child in a family and the baby will only be either girl or boy. The child cannot be both girl and boy as the gender of the child is the complementary antonym. Further examples of complementary antonyms are deadalive, young-old, and empty-full that same goes for the examples in Malay, 'mati-hidup', 'muda-tua' and 'kosongpenuh' respectively.
According to Marlyna (2005), relational antonyms or converse antonyms are pairs of opposite words where one cannot exist without the other. This antonym is recognized as 'antonimi sebalikkan' in Malay language. This antonym is a pair of words with the opposite meanings, where opposite makes sense only in the context of relationship between the meanings of the two words. There is no lexical opposite for teacher, but teacher and pupil are opposite with the context of their relationship. Another example is when there is a husband, there must be a wife. Therefore, husband and wife are relational antonym. Other examples are night-day, policeman-criminal and parent-child. In Malay language, they are 'malam-siang', 'polis-penjenayah' and 'ibubapa-anak' accordingly. Thus, we can conclude that the antonym of Malay language and English language are similar and the same.

Hyponym is a word of more specific meaning than a general or superordinate term applicable to it. For example, the word 'European', its hyponym is British, Angle, Jutes, etc.

In Malay language, the word 'Asia' has the hyponym of Malaysia, Pakistan, Japan and others. Hence, we can simplify that the hyponym between these two languages is the same (Asmah, 1983).

In conclusion, it is shown that there are similarities and differences between Malay and English languages from some aspects. They are history, phonology, influences in vocabulary (loanwords), grammar, morphology and semantics. Although these two languages come from different background, somehow they share similar characteristics such as the vowels sounds, loanwords and semantics. This proves that human has the same mindset that is to use sounds and voices to communicate in the ancient 
ENGLISH REVIEW: Journal of English Education Vol. 4, Issue 2, June 2016
ISSN 2301-7554

https://journal.uniku.ac.id/index.php/ERJEE days. The words that are loaned from one another mean they have effect on each other. Grammar is a big category which consists of both similarities and differences from many aspects, is the basic of a language. Moreover, morphology is regarding the morpheme that refers to the basic unit in a word as well as the semantics of words share similarities and contrasts among the two languages (Hazita, 2004).

Regardless the differences of these two languages, both of the languages are unique and beautiful in their ways and survive until today with their native speakers. The linguists who have categorized everything that we learn and use today, are unforgettable as these are their great works, and they shall be remembered forever.

\section{REFERENCES}

Asmah, O. (1983). The Malay Peoples of Malaysia and their languages. Kuala Lumpur: Dewan Bahasa \& Pustaka.

Asmah, O. (1986). Nahu Mutakhir Melayu. Kuala Lumpur: Dewan Bahasa dan Pustaka.

Azar, B. (1989). Understanding and Using English Grammar. Prentice Hall Regents. New Jersey.

Baker, M. (2011). In other words: A course book on translation. 2nd ed. London: Routledge.

Butt, D., Fahey, R., Feez, S., Spinks, S., \& Yallop, C. (2000). Using Functional Grammar. Sydney: National Centre for English Language Teaching \& Research.

Deterding, D., \& Salbrina, S. (2013). Brunei English: A new variety in a multilingual society. Dordrecht: Springer.

Halliday, M. A. K. (1994). An Introduction to Functional Grammar. London: Edward Arnold.

Hatim, B. (1997). Communication Across Cultures: Translation theory and contrastive text linguistics. Exeter: University of Exeter Press.
Hazita, A. (2004). Global English and English Literacy Education in Malaysia, in

Penny Lee and Hazita Azman, Global English and Primary Schools: Challenges for Elementary Education, Melbourne: CAE Press.

Imran, H. A. (2000). Contrasting Malay English Preposition Categories: Indulging in In Diverse Voices: Readings in Languages, Literatures and Cultures. Serdang: Penerbit Universiti Pertanian Malaysia.

Khazriyati, S., Tan, K. H., \& Marlyna, M. 2006. "Definiteness and indefiniteness: A contrastive analysis of the use of determiners between the

malay language and English". GEMA Online Journal of Language Studies. Volume 6 (1).

Marlyna, M., Khazriyati, S., \& Tan, K. H. (2005). "Everyone People Must Have a Best Friend. Interference of Malay Structures in English Written Discourse". Proceedings of the TLEiA Conference. Teaching and Learning of

English: Towards an Asian Perspective. Fakulti Komunikasi dan Bahasa Moden: UUM.

Murni. M. (2013). 'Fonetik dan fonologi (vokal \& konsonan)'. Retrieved from http://www.slideshare.net/murnibint imohamat/fonetik-dan-fonologivokal-konsonan

Newmark, P. (1988). A Textbook of Translation. Singapore: Prentice Hall International (UK) Ltd.

Nik, S. K. (1989). Tatabahasa Dewan Jilid 2: Perkataan. Kuala Lumpur, Dewan Bahasa dan Pustaka.

Noorizah, M. N., \& Rosniah, M. (1998) Tatabahasa Inggeris. Utusan Publications. Kuala Lumpur.

Nor, H. J. (2004). Penguasaan bahasa Melayu oleh pelajar Melayu dalam arus globalisasi. Jurnal Bahasa Jil. 4 (1), 63-95.

Ramli, Md. S., Ismail. S., Idris. A., Fadzeli. J. (2000). Penguasaan Bahasa Melayu di Kalangan Pelajar-Pelajar Sekolah Menengah Rendah: Kajian di SekolahSekolah Rancangan FELDA Negeri Sembilan. Universiti Kebangsaan Malaysia. 
Mohd Nazri Latiff Azmi, et all.

The Comparisons and Contrasts Between English and Malay Languages 